\title{
Restoration of the Martyn brothers house as a bright example of the work of the architect N.M. Socolow
}

\author{
Yuliya Petrusenko,", and Anna Ivanova-Ilicheva ${ }^{1}$, \\ ${ }^{1}$ Academy of Architecture and Arts of the Southern Federal University, Bolshaya Sadovaya Str., \\ 105/42, 344006, Rostov-on-Don, Russia
}

\begin{abstract}
The paper discusses the history of the Martyn Brothers House, as well as the practice of restoring this object of cultural heritage of federal significance. The author of the mansion is Nikolai Matveevich Sokolov (1859-1906), the city architect of the late XIX - early XX centuries in Rostov-on-Don. To characterize the measures for the protection and modern practice of restoration of one of the brightest examples of N. M. Sokolov's creativity - the Martyn Brothers House in Rostov-on-Don. The main method of research was historical analysis - the study of the origin, formation and development of objects in chronological order, as well as archival and full-scale surveys of the object, photo fixation. The characteristic of practice of restoration of works of "brick style" using Martyn Brothers House as a bright example of the work of the architect N.M. Sokolov was given. The mansion is of scientific and practical interest. During the research, the main techniques and methods used in restoration practice that can be used by modern restorers were identified. After the completion of restoration work on the site of the Martyn Brothers House, the original historical and architectural appearance of the magnificent monument of the late XIX century was restored, taking into account all the lost parts of the building.
\end{abstract}

\section{Introduction}

This paper is devoted to study the restoration practices of the Martyn Brothers House as a bright example of creativity of the architect Nikolai Matveevich Sokolov - an adherent of rational direction of architecture of the late XIX - early XX centuries. The problem of research connected with necessity of studying and accumulating best practices for the restoration and protection of works of historic architecture of the region. The architectural heritage of cities in the South of Russia is rich in examples of rational architecture "brick style", while the modern practice of restoring objects of brick architecture of the milestone of the XIX-XX centuries in most cases, it leads to a distortion of the original author's idea, measures to protect the historical brickwork lead to a change in the original appearance of the object and the loss of its aesthetic value. Often, measures to adapt to the modern

\footnotetext{
${ }^{*}$ Corresponding author: miss.smiyukha21@yandex.ru
} 
functioning of historical objects lead to irreparable losses. In these conditions, it is particularly important to study the positive experience of restoration of historical architecture objects in the "brick style". As an example, famous work of a leading city architect of Rostov-on-Don - the Martyn Brothers House - the analysis of modern practice of restoration and adaptation of cultural heritage to a new function, in this case -museum. The goal is to study and analyze the restoration design and protection of cultural heritage.

The relevance of the research is that the study of restoration practice is of scientific and practical interest. Modern restoration can be developed based on the research of previous generations' experience. Every restoration process begins with a study of the history of the monument's creation, as well as previous restorations. The relevance of this topic increases in modern conditions due to the raised interest in the historical heritage of regional architecture and the expansion of the processes of reconstruction and new construction in the historical center of the city.

To study the historical and architectural context of the work of N.M. Sokolov, the works devoted to the general characteristics of the architecture of the cities of the Lower Don and the Azov region of the XVIII - XX centuries were considered in the study, in which attention is paid to the architecture of second half XIX-beginning of XX centuries among them, Zakhariants G.N., Inozemtsev, G.A., Semarin P.V. "Rostov-on-Don" [1]; works devoted to the historical and architectural analysis of the development of the cities of the Lower Don and Azov region - O. H. Khalpakhchyan "Architecture of the Nakhichevan-onDon" [2]; G.V. Esaulov, V.A. Chernitsyna "Architectural chronicle of Rostov on Don" [3]. Historical and local history works that characterize the urban environment, economy, education and life of the population of Taganrog, Rostov-on-Don: Ilyin A.M. "History of the city of Rostov-on-Don" [4]; Esaulov, G. V. "Architectural and urban planning heritage of the South of Russia: its formation and cultural potential" [5], Esaulov G.V. "Architect of Rostov is Nikolay Sokolov" [6], Esaulov G. V. "Architecture of the South of Russia: from history to modernity" [7]; L.F. Voloshinova "Crossroads of centuries. Fate of streets, squares, architects" [8], Voloshinova L.F. "Nikolai Sokolov" [9], Voloshinova, L.F. "The happy man" [10], V. Lobzhanidze, G.Laptev, "Travels in old Rostov" [11], IvanovaIlicheva, A. M. "Rationalist tendencies in architecture of cities of the Lower Don and the Azov region in the second half of XIX - beginning of XX centuries: on the example of Taganrog, Rostov-on-Don and Nakhichevan-on-Don, Novocherkassk" [12], Baranovskiy G. V. "Anniversary collection of information about the activities of former pupils of the Institute of Civil Engineers (Building school) 1842-1892." [13]. Protection obligation No 37-16 of the object of cultural heritage (historical and cultural monuments) of the peoples of the Russian Federation: "Martyn Brothers House, XIX century", dated 26.02.2016 (Protection obligation No 37-16 of 26.02.2016). The project of the company "Retro-Style" "Capital repairs of the object of cultural heritage of federal significance "Martyn Brothers House" was studied. Repair and restoration work and adaptation to modern needs" [14]. The first works on the history of restoration belong to the turn of the XIX-XX century. In 1931, the Athens Charter was adopted at an international conference in Athens (see http://tehne.com/node/4613), which recognized the absolute value of previous epochs; introduced the refusal of complete restorations instead of preserving different stylistic layers; the main type of work on the monument was recognized as conservation. The Athens Charter initiated the formation of a scientific basis for restoration at the international level. Its principles were revised and expanded in 1964, and the Venice Charter was adopted (see http://docs.cntd.ru/document/901756982) for the conservation and restoration of monuments and places of interest. These documents, of course, had an impact on the formation of the restoration. 
The Martyn family home is located in the historical center of Rostov-on-Don on the territory of the former fortress of St. Demetrius of Rostov (1761-1835) - an important part of the historical territory of the city.

In April 1893, Polina Ivanovna Martyn applied to the Rostov city Council with a request to issue her a construction permit for a "2-storey stone house with a basement" at the corner of Bolshaya Sadovaya street and Krepostnoi lane. The works were to be carried out under the supervision of the city architect N. M. Sokolov, who was the author of the building project.

Nikolai Matveevich Sokolov was born in 1859 in Latvia in a Russian landowner family married to a German woman, he studied at Pinsk and then at the Vilna real schools. In 1880, he entered the Saint-Petersburg Institute of Civil Engineers, and graduated in 1885 with the first class civil title [12].

By the end of 1893, the building at B. Sadovaya street, 137 (now B. Sadovaya, 125, 69, Krepostnoi lane) was completed. According to the reference publication "Assessment of real estate in the city of Rostov-on-Don... in 1894", the owner of the household on the territory of which the newly built house was located was Ivan Romanovich Martyn - the father of Polina Ivanovna Martyn. Ivan Romanovich was the founder of the firm "John Martyn and Co". In 1872, Ivan Martyn opened a small wool-washing plant in Rostov (Security obligation No 37-16 of 26.02.2016).

"Martyn Brothers House" - an old mansion built more than a hundred years ago-has long been one of the brightest architectural places of interest of the main street of Rostov. It still admires the original solution of the architectural and artistic appearance, consisting of elements and motifs borrowed from the architecture of the German and Russian middle ages. The white-stone decor of the front facades with a high multi-pitched mansard roof, including an octagonal corner tent, reflects the peculiar style of the architect N.M. Sokolov. The house for the Martyn family became one of the best creations of the architect, who in the late $1880 \mathrm{~s}-1890 \mathrm{~s}$ designed and built a number of large public buildings in the city and at the same time led a wide private practice (see http://museum.ru/N47491).

I.R. Martyn's household at the end of the XIX century, in addition to the corner twostory building and the one-story wing with a basement adjacent to it from the north, also included a small gatehouse. At the western border of the site was a single-story household structure and a stable. The household also included the buildings of the "John Martyn and Co" foundry and mechanical plant, located along Krepostnoi lane and Suvorov street (formerly Malo-Sadovaya). By 1900, the owner of the house was listed as Polina Ivanovna Martyn. Since 1908, Polina's brothers, Vasily Ivanovich and George Ivanovich Martyn, have become owners. By 1915, Polina's Ivanovna third brother, Ivan Ivanovich Martyn, became the co - owner of the house.

With the establishment of Soviet power in the early 1920s, the Martyn brothers' household was municipalized. The second floor of the mansion and the one-story wing were used for communal housing; the living rooms and rooms on the first floor were intended for organizations. During its operation, significant losses occurred, the premises were redeveloped, and the details of the decoration were destroyed (Figure 1).

In the post-war years, the first floor of the building housed the Rostov housing Department of the Kirov district, the second floor and the premises in the north wing were used for housing. The gatehouse was used for second-hand book sales in the 1960s and 1990s.

Since 1987, the ground floor was referred for an exposition of the Rostov regional branch of Union of Artists of the RSFSR, the rooms on the second floor to the Russian Fund of Culture. In the early 1990s, one room was occupied by the Rostov branch of the Union of Architects. From the mid-1920s to 2005, the northern and western borders of the 
yard changed. In the early 2000 s, a one-story household structure and stable located to the west of the house were demolished.

In early 2003, the building was transferred to the state Technical Commission under the President of the Russian Federation for the South Federal district (Protection obligation No 37-16 of 26.02.2016).

In April 2007, the building, which was in disrepair at the time, was transferred to the balance of the Museum-reserve. Taking into account the reconstruction of lost architectural elements and details on the basis of preserved analogues and photographic documents in 2007-2008, scientific and design documentation was developed for the repair and restoration works, and today a lot of work has been done to restore the building to its historical appearance. From 2009 to 2015, according to the project of "Retro-Style" LLC, repair and restoration works were carried out to ensure the preservation of the cultural heritage object "Martyn Brothers House, XIX century" [13].

Chronicle of the restoration:

2008 - scientific and design documentation was developed, taking into account the reconstruction of lost architectural elements and details on the basis of preserved analogues and photographic documents. The positive conclusion of the Federal state unitary enterprise "Rosgosexpertiza".

2009 - based on the results of the survey, the building foundations were reinforced with the use of drilling and injection piles.

2010 - replacement of wooden inter-floor coverings with cast-in-place reinforced concrete, roof construction; reconstruction of the tent spire and dormer window spires.

2011 - restoration of brickwork, replacement of external water supply and sewerage networks, heating networks.

2012 - interior decoration of premises, floor arrangement, installation of staircase structures.

2013 - strengthening the foundations of the terrace and its construction; covering the floors with granite; installation of lighting devices.

2014 - restoration of the facade and balconies; restoration of mirrors of stoves; reconstruction of wrought-iron gates, installation of lanterns (see http:/ / www.sholokhov.ru/) (Figure 2)

In 2009, due to the deformation of load-bearing structures due to the construction of a wide scale International Congress center and the presence of subsidence and weak soils, according to the results of surveys, the foundations of the building were reinforced with the arrangement of drilling and injection piles. In accordance with the works production technology in 2010-2011 wooden floor slabs were replaced with monolithic reinforced concrete ones with metal beams and wooden truss systems were replaced with load bearing metal structures; installation of later window openings one-story wing by brick of the old model with the provision of dressing and keeping the pattern of the brickwork; reconstruction according to the revised dimensions of window and door fillings; reconstruction of forged grills; constructed water, sewer and heating networks; created internal systems of engineering support of the functioning of the building: electricity, heating, ventilation, climate control, security and fire alarms, video surveillance, etc. (see $\mathrm{http}: / /$ museum.ru/N47491). The main task of repair and restoration work is to preserve the historical and cultural value of decorative elements of facades, interiors, including a stove with tiled decor, bronze appliances, the main staircase of prefabricated metal cast ornamented and figured elements, which are a sample of artistic casting of the late XIX century of Rostov plant "John Martyn and Co".

Today, the building of the Martyn Brothers House is conditionally divided into letters: Lit. A, A1, G-shaped configuration in the plan, variable number of floors (Figure 3, figure 4). Lit.A, which occupies the corner part, is two-storied with a mansard and a roof of 
complex configuration, brick, painted with facade compositions. Lit. A1, attached to the north-eastern part of lit. A and located along the red line of the development of Krepostnoi lane, one-story with a basement and hip roof, brick. The gatehouse (lit.B.) detached, adjacent to the arch of the courtyard passage from the side of the street. B. Sadovaya, onestory with a cross roof, brick, painted facade compositions.

Space-planning solution of lit. A before the repair and restoration work, was provided with a corridor-enfilade arrangement of internal rooms, as well as an internal staircase and a lobby of the main entrance allocated in the western part. Today, the space-planning solution is mostly preserved. A wide balcony-terrace covers the courtyard passage along the western facade.

On the main southern facade of the building there is an information board: "Monument of federal significance. Martyn Brothers House, 1893 arch. N. M. Sokolov. Protected by the State".

The walls of the building are made of old-style red ceramic full-bodied brick on a complex lime mortar. The outer wythe, presumably made of face bricks with stitched seams, is painted with facade compositions. The condition is satisfactory. Separate window openings are bricked up on the northern facade.

The roof structure of letters A and A1 is multi-pitched. Coating of painted rolled steel. Dormer and mansard windows are wooden glazed, sewn with painted steel rolling. Everything is new, since the dormer windows were lost.

The roof of lit. B (gatehouse) cross design-new structure.

\subsection{Architectural and artistic appearance}

The building is located at the intersection of Bolshaya Sadovaya street and Krepostnoi lane. Due to this location in the development of the block, the building has two front facades facing the adjacent streets and united by a corner, semicircular in plan, tower-like volume, topped by a pyramidal tent. The architectural and artistic appearance of the house is made in the style of pseudo-gothic and consists of elements and motifs taken from the architecture of the German and Russian middle ages. The wall planes combine European red brick and Russian "white stone" decor.

Architectural and artistic image of the entrances of the south and east facades of brick decoration forms: profiled crowning cornice of white stone; the blind arcade on stepped bars; wall blades on stepped brackets and complex protrusions that imitating machicolations completed with forceps; the pediments in the form of a reclining arch with a gable end topped with a stylized finial, in the design of window openings on the second floor; parapet pants with tracery imitation; intercommunication pull teeth. Pediment in the form of a box arch in the design of window openings on the first floor; a massive outer sills of the window openings of the first floor; the ledges of the walls on the second floor of unscrambling of lit.A on stepped brackets, gable ends, promising massive shallow canted lintels above the openings of the first floor and arched doorways, of dormer windows in the end; ledges of the wall on the second floor corner of volume of lit. A with a gable end and lancet openings of the dormer window and balcony door. Balconies in the second floor level of the central part of the southern facade and the corner volume of the lit.A complement the appearance of the building on powerful stepped brackets, with cast-iron railings, decorated with tracery and corner brick pedestals.

The main entrance to the building is represented by a wooden blind double-leafed paneled door with a glazed transom and decorative linings, a gable roof canopy made of prefabricated wrought-iron openwork elements: brackets, frieze, tympanum.

The symmetry of the west facade of lit.A emphasizes the central unscrambling, topped with a three-stage attic with an arched frieze and a double lancet dormer window, framed 
by pediments and blades. The extreme window openings of the first and second floors are blind. To the unscrambling of the western facade of lit.A, at the level of the second floor, adjoins a balcony-terrace, based on a structure of columns and pointed arches. The balcony railing consists of precast cast iron elements: octagonal corner pedestals with finials and grilles with a tracery.

The composition of the eastern facade of the one-story lit A1 forms the rhythm of blind windows and walls blades on stepped brackets. The architectural and artistic appearance is represented by a brick decor: a crowning cornice with torn gable endings of the blades; a frieze with niches filled with a curb; false projections of the blades on stepped brackets, completed with forceps imitating machicolations; a rod with teeth; pediments in the form of box arches in the design of blind window openings; massive external sills. The decoration of the western façade of lit.A1 is represented by a crowning cornice on stepped bars; shadows; window draught; pediments in the form of box arches. Brick decor of the gatehouse lit.B presents a gable end, arched dormer windows and ogee-shaped pediments of the window openings. The decor is brick and stone, painted with facade compositions (Security obligation No 37-16 of 26.02.2016).

During the Great Patriotic War, the buildings were not significantly damaged. During the renovation of the house in the 1950s, the roof structure and roof of the main volume of the attic were replaced, three dormer windows on the southern slope and two windows on the sides of the tent were dismantled. By the Decree of the Head of the Administration of the Rostov region from 14.03.1994 No 69 "Martyn Brothers House" is taken for protection as a monument of history and culture of local significance. By Decree of the President of the Russian Federation No 176 of 20.02.95, the building received the status of a monument of federal significance. The building is a city mansion with a courtyard plot. It includes: a two-story volume that occupies an angular position in the block, and an adjacent one-story wing with a basement. The western terrace was adjoined by a small gatehouse, located on the southern facade along the red line of Bolshaya Sadovaya street. A passage to the courtyard was formed under the terrace.

In the composition of the front facades of the main volume, there are two unscrambling, flanking the corner volume, crowned with a tent, as well as the south-western, accentuating the main entrance. Unscrambling ends gable pediments with lancet window openings.

The front facades are a single composition, united by the rhythm of openings and niches, sections of inter-floor belts, the ledge of the plinth, the active crowning cornice and arched frieze, and the inter-window blades of the upper tier. The composition of the western facade is symmetrical, emphasized by the central unscrambling, topped with a stepped attic with a double lancet window of the mansard.

Courtyard facades are much more concise than front ones. The few decors of the northern facade of the two-story volume is represented by a low crowning cornice with crenellations, P-shaped window pediments and sills. The facade of the one-story wing along the lane forms a series of shallow niches, decorated with pediments and window sills, similar to the openings of the 1st floor of the main volume and wall blades with gable finials raised above the cornice. The building, constructed using pseudo-Gothic forms, is of historical and artistic interest as a rare surviving example of a city mansion [13].

\section{Methodology}

The method is based on the research of this issue, search and study of general and special literature, documents in archives, Museum collections. Visual inspection of the facility built on the project Sokolov N. M. (1859-1906) and preserved until now, photo fixation, field study, generalization of already known materials, a detailed study of the project for 
restoration of Martyn Brothers House, the discovery of new documents, the introduction into scientific use of new facts.

\section{Research results and discussion}

The study examined the measures used in the restoration of the Martyn Brothers House. Survey bearing structures was done in 2005 - by "NPP "Alektich" LLC, a visual survey to capture the state of the building prior to commencement of construction works of the International Cultural Center. In 2006, "BTP" LLC, made sample survey of building structure, determination of strength properties of brick and concrete. A recommendation was developed to strengthen the building structures and foundations of the building, preventing the possible impact of new construction in the surrounding area on the surveyed building. The survey of building structures was carried out by the Institute "Rostov Promstroiniiproekt" JSC under the contract No 77/274-07 dated 31.10.2007, concluded with Federal state cultural institution "State Museum reserve of M. A. Sholokhov". Strengthening of the foundation is adopted according to the design scheme in the form of a pile foundation with cutting through subsidence and weak soils and transferring pressure from the building to the semi-solid loam of the support layer.

The project considered the restoration of facades. Interiors of individual rooms, interior elements, adaptation of the building to modern needs, taking into account the functional use of the existing mansard space of the main volume and the attic space of the northern wing.

The project was supposed to restore the main facades of the building for the first half of the XX century (until the 1950s.), which is due to the historical availability of photographic documents and nature studies of the monument [13].

\subsection{Structural measures}

Strengthening of window and door openings, injecting cracks in the walls, replacing wooden floor slabs with monolithic reinforced concrete on metal beams, taking into account the functional use of the premises and ensuring the required protection of exhibition halls. The wooden truss system was replaced with metal structures, taking into account the preservation of volume-compositional and style-forming characteristics, as well as the adaptation of the mansard and attic space for modern use.

\subsection{Space-planning solutions}

The project provided for the adaptation of the building to the modern needs of the Museum (Federal state cultural institution "State Museum reserve of M. A. Sholokhov") with the maximum possible preservation of the existing planning structure, the implementation of separate planning measures that ensure functional feasibility, fire safety during the operation of the building. The project proposed the construction of a staircase from the second floor to the mansard in a room located in the alignment with the existing main staircase. In connection with this, a second evacuation exit was provided from the premises of the second floor and mansards, through open transition galleries and a stairwell built on the adjacent territory. During the adaptation of the cultural heritage object to the new function and in accordance with the current standards, the project provides for the construction of a ramp to ensure unhindered access for low-mobility groups of the population to enter the first floor of the building, where the exhibition halls are located. During the adaptation of the building, the project provided for the placement of the following premises in the building. In the basement level: vent chamber, electrical panel, 
heat point, technical rooms (control frame). At the ground floor level: lobby, cloakroom, exhibition halls (up to 25 visitors at a time), utility room, cleaning equipment room, security room, recreation room for museum employees, universal cabin (for people with limited mobility). At the second floor level: offices of museum employees, department of the Museum-reserve for organizing excursions, office of the Director, meeting room, toilets. Mansard above the one-story wing: cleaning equipment room, administrator's office. Recreation room for Museum employees. Mansard above the main volume: information and museum center, hardware room, utility room, hall. The gatehouse provides for the placement of a security room.

The brickwork and stone masonry were restored and recreated. Cleaning of brick and stone masonry of preserved sections of walls from cement layers and moss.

Reconstruction of lost and repositioned sections of walls made of old-style bricks (270x130x70mm) based on the original elements. Laying of late window openings of a single-story wing with old-style bricks with the provision of bandages and compliance with the pattern of masonry. The restoration of the brickwork was made by the method of bricklaying with old-style bricks $(270 \times 130 \times 70 \mathrm{~mm})$. During the restoration of the masonry, the order and removal of elements of the brick decoration of the preserved fragments were observed. For the restoration of profiled masonry elements, chiseled bricks were used, made according to templates taken from nature. Completion of individual sections, taking into account the visual perception of the integrity of the masonry.

Reconstruction of disassembled terrace structures in a new material using old-style bricks; reconstruction of disassembled columns of balcony railings made of old-style bricks; restoration of cast-metal terrace railings, balconies (with the reconstruction of bowstrings, handrails), installation in the original position. Reconstruction of wooden window and door blocks based on the existing analogues, taking into account the degree of protection of the premises of the exhibition halls on the first floor. Reconstruction of internal paneled shutters and window blocks of the building based on their preserved analogues; reconstruction of the front doors and doors under the terrace similar to the preserved details of the original front doors. Reconstruction of window and door false latches, brass handles on the original preserved parts-models. Tile stoves that are objects of protection, their clearing and restoration of lost elements. Interior decoration: restoration of the main staircase, reconstruction of the damaged fence post on the existing example model cast iron. Restoration of plaster interior decoration, plaster and stucco decoration: reconstruction of high-quality lime-cement plaster of capital walls, slopes, ceilings; reconstruction of plaster cornice and ceiling rods; decoration of exhibition halls and individual rooms with plaster profiles, rosettes made in the style of preserved rods.

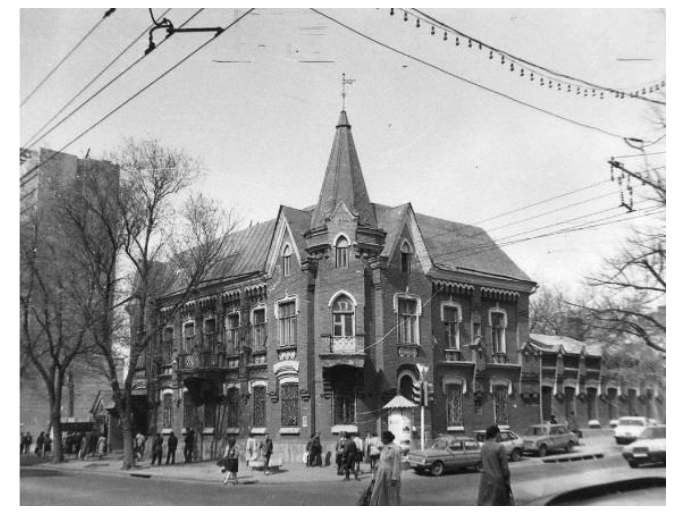

Fig. 1. Martyn Brothers House in the postwar years, arch. N. M. Sokolov, Rostov-on-Don (see. http://hotel7nebo.ru/images/page/45_1.jpg). 
According to historical documents, the wooden dormer windows of the mansard and the tents above them, the spire of the tent and the spires of the dormer windows were recreated. The three-dimensional decorative details of the spires and ribs of the tents were made by hammering out of copper sheet. To recreate the plaster elements of stucco decoration, gypsum of the G-7 brand of the Samara deposit was used [13].

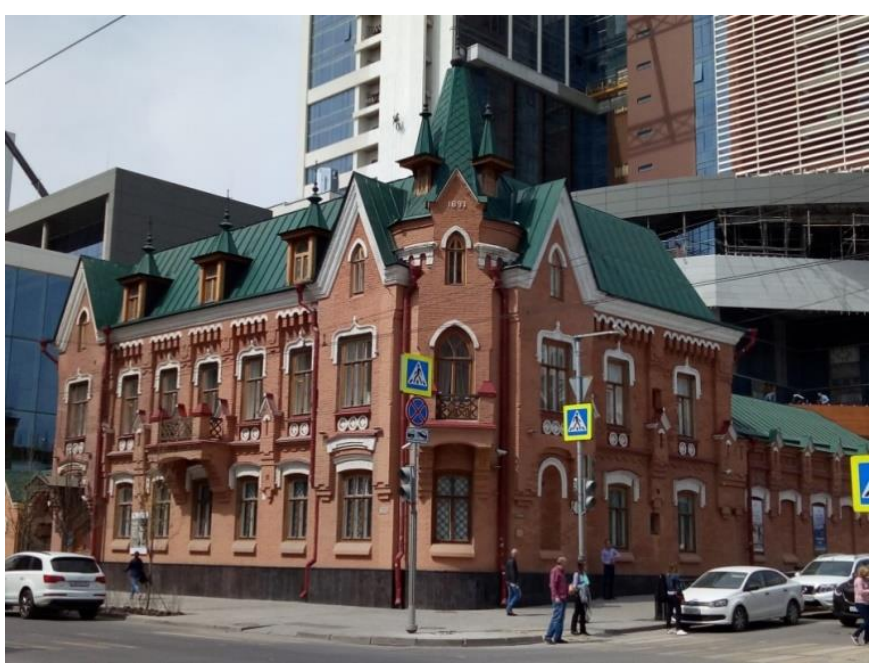

Fig. 2. Martyn Brothers House after the restoration, the arch. N. M. Sokolov, Rostov-on-Don. Photo Petrusenko Y. V., 2018.

\section{Conclusions}

1. The research found out that the study of restoration practice is of scientific and practical interest, since modern restoration can't develop without understanding the previous experience.

2. The key provisions of the Martyn Brothers House restoration concept have been identified, and techniques and methods used in restoration practice that can be used by modern restorers have been identified.

3. After the completion of restoration work on the site of the Martyn Brothers House, the original historical and architectural appearance of the magnificent monument of the late XIX century was restored and acceptable measures were taken to adapt the building's premises to the function of a Museum.

The study was funded by RFBR, project number 19-31-27001

\section{References}

1. G. N. Zakharyants, G. A. Inozemtsev, P. V. Semerin, Rostov-on-Don, Rostov n/D, Rostizdat (1949)

2. O.H. Khalpakhchyan, The architecture of the Nakhichevan-on-Don (1988)

3. G. V. Esaulov, V. A. Chernitsyna, Architectural chronicle of Rostov on Don, 288 (1999)

4. A.M. Ilyin, History of the city of Rostov-on-Don (1991)

5. G.V. Esaulov, Rostov Architect Nikolai Sokolov 2 (1998) 
6. G. V. Esaulov, Architecture of the South of Russia: from history to modernity. Essay. Monograph, 568 (2016)

7. G. V. Esaulov, PhD Thesis, (2004)

8. L.F. Voloshinova, The crossroads of centuries. The fate of streets, squares, and architects (2004)

9. V.N. Lobzhanidze, G.F. Laptev, Travel through the old Rostov (1997)

10. A.M. Ivanova-Ilicheva, Rationalistic trends in the architecture of the cities of the Lower Don and the Azov region of the second half of the XIX-early XX centuries: on the example of Taganrog, Rostov-on-Don and Nakhichevan-on-Don (2000)

11. Milja Penić, Golovina Svetlana, Vera Murgul, Procedia Engineering, 117, (2015), 883-890, https://doi.org/10.1016/j.proeng.2015.08.165

12. Cemil Akcay, Baris Sayin, Baris Yildizlar, Construction and Building Materials, 132, 1 Pages 383-394 (2017) https://doi.org/10.1016/j.conbuildmat.2016.12.002

13. Hülya Yüceer, Journal of Cultural Heritage, Volume 13, Issue 4, 419-425 (2012) https://doi.org/10.1016/j.culher.2011.12.002

14. G. V. Baranovskiy, Anniversary collection of information about the activities of former students of the Institute of Civil Engineers (Construction school) 1842-1892 (1893)

15. Retro-Style. "Major repairs of the cultural heritage object of Federal significance "Martyn Brothers House". Repair and restoration work and adaptation to modern needs" (2008) 